\title{
Transformasi Cerita Rakyat ke dalam Naskah Lakon Berbahasa Inggris dalam Pembelajaran Drama
}

\author{
AMBHITA DHYANINGRUM \\ ambhita.dhyaningrum@unsoed.ac.id \\ HANIFA PASCARINA \\ hanifa.pascarina@unsoed.ac.id \\ Program Studi Sastra Inggris, Universitas Jenderal Soedirman \\ Purwokerto, Indonesia
}

dikirim: 30/01/2020 diperbaiki: 26/12/2020 diterima: 28/12/2020 DOl: 10.22515/ljbs.v5i2.2142 hlm: 189-199

ABSTRACT In etnopedagogic-based drama learning by the students of English Study Program, the exploration of local wisdom values can be carried out among others by transforming folklores into play scripts in English. The transformed folklores can then be performed on stages. In the process of transforming a script from its hypogram, a supporting skill in the form of integration between creative writing and English as a Foreign Language Mastery (EFL) mastery is absolutely necessary. Therefore, it takes an interdisciplinary approach between those two domains of expertise to succeed the transformation process. This research employed descriptive-qualitative method with contextual grounded case study approach. It was aimed at describing the process of transformation of Banyumas folklore texts to English play scripts ranging from the intrinsic elements to the language aspects in the play. The findings showed that there were changes in the characters, settings, plots as well as the conflicts of the stories. Meanwhile, regarding the language used, there were found a number of grammatical mistakes in using possessive pronouns, verbs, word order, tenses, and diction.

Keywords: drama, etnopedagogy, transformation, folklore, play script

PENDAHULUAN Pembelajaran drama merupakan kegiatan yang melibatkan aktivitas reseptif dan produktif. Kegiatan reseptif berfokus pada pemahaman dan penghayatan karya drama, sedangkan kegiatan produktif lebih menekankan pada kegiatan merancang dan mementaskan drama. Pemahaman dan penghayatan karya drama mencakup materi antara lain sejarah perkembangan drama, genre drama, elemen-elemen drama, dan teori kepanggungan, sedangkan aktivitas produksi drama meliputi perencanaan produksi, dan pementasan sebagai luarannya. Pada pembelajaran drama berbasis etnopedagogi, luaran pembelajaran diarahkan pada penggalian nilai-nilai kearifan lokal. Wujud kearifan lokal yang ada dalam masyarakat berupa budaya yang berupa nilai, norma, hukum adat, etika, kepercayaan, seni, dan adat istiadat. Penggalian nilai-nilai ini diterapkan pada produksi naskah yang akan dipentaskan.

Penelitian ini bertujuan menganalisis yang pertama, bagaimana transformasi cerita rakyat Banyumas ke dalam naskah lakon berbahasa Inggris yang dilakukan oleh mahasiswa semester empat program studi Sastra Inggris, Fakultas IImu Budaya, Universitas Jenderal Soedirman; dan kesalahan apa saja yang ditemukan dalam penulisannya di dalam bahasa Inggris.

Penelitian tentang berbagai transformasi teks sastra ke media lain sudah pernah dilakukan oleh Gillespie (2014) dalam The Art of Literary Adaptation and English-Language Film Interpretations of Russian Literature Anna Karenina yang menganalisis isu penerjemahan teks sastra melalui adaptasi film. Hasilnya menunjukkan bahwa karya sastra lama punya peran unik dan mengubah paradigma dalam perkembangan sinema Rusia. Adaptasi digunakan untuk mengeksplorasi perubahan prioritas dan mengungkapkan gagasan tentang nasionalisme dan menghilangkan sensor klasik dalam hal 
keruntuhan sosial, hubungan seksual, ambisi imperialisme, nasionalisme dan hubungan individu dalam negara.

Selanjutnya, Watmi (2014) dalam penelitiannya Transformasi Cerpen Di Atas Sajadah Cinta Karya Habiburrahman El Shirazy Menjadi Naskah Drama Panggung Dalam Pembelajaran Apresiasi Drama Di Kelas X SMA menganalisis unsur intrinsik yang terdapat dalam cerpen Di Atas Sajadah Cinta dan teknik mentransformasikan cerpen ke dalam naskah drama. Hasilnya memaparkan unsur-unsur intrinsik yang terdapat dalam cerpen Di Atas Sajadah Cinta, langkah-langkah mengubah cerpen menjadi naskah drama panggung, serta model pembelajaran apresiasi drama di kelas X SMA Negeri Purworejo menggunakan bahan ajar transformasi cerpen dengan cara menjelaskan persamaan dan perbedaan antara cerpen dengan drama panggung, menjelaskan langkah-langkah mengubah cerpen menjadi naskah drama panggung, serta evaluasi mengubah cerpen Di Atas Sajadah Cinta menjadi naskah drama panggung.

Sementara itu, Sumpeno (2014) dalam penelitiannya, Akulturasi Budaya dalam Bentuk Adaptasi Drama Karya Sutradara Suyatna Anirun Dari Studiklub Teater Bandung menganalisis bentuk adaptasi drama karya sutradara Suyatna Anirum. Hasil penelitiannya menunjukkan bahwa Studiklub Teater Bandung berupaya mengakulturasikan bentuk budaya asing dengan bentuk budaya Indonesia. Wujudnya adalah pementasan dama dengan budaya campuran (akulturasi budaya).

Kemudian, Perdikaki (2017) dalam Film Adaptation as Translation: an Analysis of Adaptation Shifts in Silver Linings Playbook melakukan penelitian terhadap adaptasi film sebagai modalitas dalam penerjemahan dan memberikan analisis sistematis pada perubahan yang terkaji dalam adaptasi novel ke layar lebar. Perubahan-perubahan ini, misalnya dalam pergeseran adaptasi, diteliti dengan model yang terdiri atas komponen deskriptif/komparatif dan komponen interpretatif.

Terakhir, Leitch (2018) melakukan penelitian dengan judul Adaptation; the Genre. Dalam artikelnya, Leitch menganalisis pada konteks resepsi dan analisis, yaitu genree adaptasi itu sendiri. Ada empat penanda genre yang umum yaitu setting waktu; musik pada zamannya; obsesi terhadap penulis, buku, maupun kata-kata; dan informasi setting.

Drama sering kali dikaitkan dengan teater. Istilah "drama" berasal dari bahasa Yunani Kuno, draomai yang berarti bertindak atau berbuat. Teater juga berasal dari bahasa Yunani, theatron, yang artinya adalah tempat atau gedung pertunjukan. Hubungan kata "teater" dan :drama" bersandingan sedemikian erat seiring dengan perlakuan terhadap teater yang mempergunakan drama lebih identik sebagai teks atau naskah atau lakon atau karya sastra (Soemanto, 2001). Drama berkaitan dengan lakon atau naskah yang akan dipentaskan, sedangkan teater adalah visualisasi drama yang dipentaskan di atas panggung.

Batasan drama, menurut Webster's New International Dictionary, adalah suatu karangan, kini biasanya berbentuk prosa, yang disusun untuk pertunjukan dan dimaksudkan untuk memotret kehidupan atau tokoh, yang bermaksud memetik beberapa hasil berdasarkan cerita dan sebagainya, suatu lakon, direncanakan dan disusun sedemikian rupa untuk dipertunjukkan oleh pelaku di atas pentas (Tarigan 1984, 70). Pada intinya, drama adalah cerita yang berisi tentang tema tertentu, yang diungkapkan melalui dialog dan perbuatan para tokohnya. Dialog merupakan teks utama dalam naskah 
drama. Selain teks utama, ada teks tambahan yang berupa informasi mengenai latar waktu, tempat, dan suasana kejadian.

Drama dikelompokkan sebagai karya sastra karena menggunakan media bahasa (Tsai, Chang \& Huang, 2016). Drama, seperti halnya karya sastra yang berbentuk prosa, memiliki unsur-unsur intrinsik dan ekstrinsik. Unsur intrinsiknya masing-masing berupa (1) tokoh, peran, dan karakter; (2) motif, peristiwa, konflik, dan alur; (3) latar dan ruang; (4) penggunaan bahasa; (5) tema dan amanat (Hasanuddin 1996). Sementara itu, unsur ekstrinsik drama meliputi latar belakang pengarang atau kondisi sosial budaya yang melatari karya.

Perbedaan dunia kata pada teks tertulis (sastra) dan dunia audio visual pada pementasan drama akan menghasilkan sesuatu yang berbeda. Hal ini disebabkan oleh keterbatasan yang dimiliki masing-masing media. Selain itu, tentu saja proses transformasi ini sangat dipengaruhi oleh proses resepsi, pembacaan, sutradara, atau penulis lakon tersebut. Tak lepas pula oleh interpretasi, tujuan, pesan, atau misi dan keinginan penulis naskah atau sutradara. Oleh karena itu, sangat mungkin terjadi muncul perbedaan ideologi antara pementasan drama terhadap teks sastra sebagai hipogramnya (Arinta 2019). Damono $(2005,96)$ menyatakan bahwa berkaitan dengan proses transformasi ini, akan terjadi alih wahana yang merupakan proses perubahan satu jenis kesenian ke kesenian lain. Misalnya, yang terjadi pada ekranisasi, suatu adalah suatu proses pelayarputihan atau pemindahan/ pengangkatan sebuah novel ke dalam film (Eneste 1991). Atau dalam transformasi tek sastra ke dalam lakon, yang memindahkan teks sastra ke dalam bentuk lakon yang akan diproyeksikan di atas panggung. Perbedaan wahana ini tentu saja akan memengaruhi cara dan bentuk penyajian cerita.

Proses transformasi dari teks sastra menjadi naskah lakon bukan sekadar memindahkan wahana (media) tetapi juga memindahkan ruang, waktu, penokohan, dan budaya pada pementasan drama. Dalam proses ini dibutuhkan kreativitas dan improvisasi untuk dapat menghidupkan kembali gagasan-gagasan yang ada di dalam teks hipogram ke bentuknya yang baru. Jika terjadi ketidaksuksesan sebuah karya adaptasi bukan terletak pada ketidaksamaannya dengan teks yang diadaptasi tetapi lebih pada miskinnya kreativitas dan keterampilan untuk menangkap keutuhan teks tersebut (Hutcheon 2006, 20).

Transformasi, atau biasa juga disebut dengan adaptasi, merupakan proses penyesuaian dan interpretasi teks terdahulu ke dalam teks baru dapat merujuk pada tiga hal; pertama, pemindahan suatu karya yang dikenal dari satu bentuk ke bentuk lain, atau dengan kata lain sebuah produk yang berwujud (process of transposition). Kedua, sebuah proses kreatif (process of creation) yang melibatkan reinterpretasi dan rekreasi. Ketiga, merupakan bentuk intertekstualitas, adaptasi merupaan cara menuliskan kembali cerita yang sama dengan sudut pandang berbeda (Hutcheon 2006, 8).

Melalui adaptasi, berbagai bagian dari unsur-unsur dari karya sastra sebelumnya direformulasi, disesuaikan, atau bahkan dihilangkan. Proses adaptasi dapat membatasi atau bahkan disaat yang bersamaan membuka kemungkinan baru dalam bercerita. Namun begitu, membandingkan keduanya tetap menjadi studi penting, terutama dalam kaitannya dengan usaha kita lebih memahami hakikat masing-masing jenis kesenian tersebut (Damono 2009, 85). Karya hasil adaptasi telah menjadi sebuah karya baru yang utuh, meskipun sering ditemui beberapa komponen yang sama dengan 
karya sebelumnya. Karya hasil adaptasi dengan karya asli (karya yang diadaptasi) memiliki nilai yang sama (Boggs 1991, 219-225).

Hinnon (2014) menemukan tiga penyebab dari kesalahan menulis dalam bahasa Inggris pada pembelajar bahasa Inggris sebagai bahasa asing (English as a Foreign Language/EFL). Kesalahan-kesalahan tersebut yaitu: negative transfer dari bahasa ibu (Proses menerjemahkan dari bahasa ibu ke dalam Bahasa Inggris yang tidak tepat), keterbatasan pengetahuan terhadap bahasa sasaran (pengetahuan tentang bahasa Inggris yang terbatas), serta perbedaan kata-kata dan struktur kalimat antara bahasa ibu dan bahasa target (perbedaan kosakata dan struktur kalimat dari bahasa ibu dengan bahasa Inggris). (Sermsook 2017) Tipe kesalahan tersebut antara lain dikemukakan oleh James ke dalam lima kategori yang meliputi (1) kesalahan gramatikal (adjective, adverb, article, noun, possession, pronoun, preposition, dan verb); (2) kesalahan substansi (penggunaan huruf kapital, tanda baca, dan ejaan); (3) kesalahan leksikal (pembentukan kata dan pilihan kata/diksi), (4) kesalahan sintaksis (koordinasi, subordinasi, struktur dan susunan kalimat), dan (5) kesalahan semantik (komunikasi ambigu dan miskomunikasi) (James 1998).

METODE Penelitian ini bersifat kualitatif deskriptif, dan merupakan studi kasus PENELITIAN terpancang yang bersifat kontekstual. Fokus penelitian telah ditentukan yaitu menganalisis transformasi teks cerita rakyat Banyumas ke dalam naskah lakon berbahasa Inggris, baik dari unsur intrinsiknya berupa tokoh, peran, karakter, motif, peristiwa, konflik, alur, latar, tema, serta amanat, dan kesalahan apa saja yang ditemukan dalam penulisannya di dalam bahasa Inggris.

Sumber data yang akan digunakan untuk keperluan penelitian ini adalah cerita rakyat Banyumas yang berjudul Babad Pasir Luhur atau Kamandaka dan Djaka Mruyung: Si Anak Hilang yang dtransformasikan menjadi Djaka Mruyung: The Lost Boy. Data objektifnya berupa kata-kata, kalimat, dan dialog yang terdapat dalam kedua naskah cerita yang telah dicatat dan diklasifikasikan berdasarkan format pencatatan dan selanjutnya dianalisis.

Pemerolehan data dalam penelitian ini dilakukan dengan metode observasi dengan pengamatan langsung dan pencatatan sistematis pada objek yang diteliti, yaitu tahapan transformasi teks cerita rakyat Banyumas ke dalam naskah lakon berbahasa Inggris. Setelah metode observasi dilakukan, dilakukan content analysis atau analisis isi, yang merupakan variasi bentuk dari analisis dokumen. Yin (dalam Sutopo 2006, 81) mengemukakan bahwa content analysis merupakan cara menemukan beragam hal sesuai dengan kebutuhan dan tujuan penelitiannya.

Analisis akan dilakukan dengan cara memaparkan hipogram berupa teks saduran cerita rakyat Banyumas, Babad Pasir Luhur (Kamandaka) dan Djaka Mruyung: Si Anak Hilang, mendeskripsikan data yang berhubungan dengan struktur naskah lakon Babad Pasir Luhur (Kamandaka) dan Djaka Mruyung:The Lost Boy, Membandingkan reformulasi antara teks hipogram dan hasil transformasinya, dan menganalisis aspek kesalahan penulisannya dalam bahasa Inggris.

RINGKASAN Di kadipaten Galuh Pakuan, kerajaan Pajajaran, hiduplah adipati bernama CERITA Munding Wilis dan isterinya. Suatu saat sang istri yang hamil tua menginginkan seekor kijang berkaki putih. Sang adipati pun pergi ke hutan mencari hewan yang diinginkan istrinya. Dalam perjalanan pencairan, mereka dirampok. Mereka tidak disakiti, tapi disuruh pulang dengan berjalan kaki. 
Sesampai di kadipaten, sang istri sudah melahirkan seorang anak laki-laki tampan yang memiliki "toh wisnu" di tangannya. Namun, tak lama kemudian, Kadipaten Galuh Pakuan diserang sekawanan perampok pimpinan Abulawang. Semua dijarah, dan sang anak pun diculik

Sang adipati dan istri lalu bertekad mencari putranya. Sang adipati menyamar sebagai orang biasa dengan nama Ki Sandi. Mereka berjalan ke timur, menyusuri pegunungan, hutan, karang padesan dan semuanya, tapi tidak juga menemukan keberadaan para perampok.

Djaka Mruyung yang diasuh oleh Abu Lawang tumbuh menjadi pemuda gagah, tampan dan pemberani. Darah adipati yang arif dan bijaksana mengalir dalam dirinya, membuatnya memutuskan meninggalkan lingkungan perampok. Djaka Mruyung bertemu dengan Ki Mranggi dan diangkat menjadi muridnya. Setelah dirasa cukup menimba ilmu, Ki Mranggi memerintahkan Djaka Mruyung melakukan perjalan ke timur, mencari hutan bernama Pakis Aji untuk dibabat dan dibangun pemukiman baru yang kelak akan menjadi negeri yang besar, makmur, gemah ripah loh jinawai. Dalam perjalanan, Djaka Mruyung bertemu seorang laiki-laki bernama Telangkas yang membantunya menunjukkan arah ke Pakis Aji. Bersama orang-orang di sekitar hutan, ia membabat hutan pakis aji. Di tengah pembabatan itu, mereka menemukan seekor ular. Ular itu pun dibunuh dan dibakar beramairamai. Tanpa disadari, api menjalar membakar hutan.

Berita kebakarn hutan itu sampai ke telingan adipati kutanegara bernama Adipati Nglangak. Sang adipati marah besar dan memerintahkan prajuritnya menangkap Djaka Mruyung dan yang lainnya supaya dihukum sesuai ketentuan hukum di Kutanegara.

Sementara itu, Ki Sandi dan istrinya bertemu dengan Ki Mranggi. Mereka pun menceritakan jati diri mereka dan tujuan mereka. Mendengar semua cerita tersebut, Ki Mranggi berkesimpulan bahwa anak laki-laki yang dicari Ki Sandi dan istrinya tak lain adalah muridnya, Djaka Mruyung.

Sementara itu, Djaka Mruyung akhirnya dijebloskan ke penjara. Karena menunjukkan sikap baik selama di penjara, akhirnya ia dilepaskan.

Suatu ketika, kadipaten Kutanegara mengadakan sayembara untuk memilih calon senopati Kutanegara. Djaka Mruyung memenangkan pertandingan itu dan ia pun diangkat menjadi senopati kadipaten Kutanegara dan dinikahkan dengan Dewi Pandanayu, putri kedua Adipati Nglangak. Menjelang acara pernikahan, datanglah Ki Sandi atau Adipati Munding Wilis dan istrinya, dengan diantar Telangkas. Ki Sandi menceritakan tujuan kedatangannya serta cerita tentang pencarian anaknya. la kemudian mohon ijin untuk melihat ciri-ciri "toh wisnu" di tangan Djaka Mruyung. Setelah diperiksa, ternyata benar bahwa Djaka Mruyung adalah anak yang bertahuntahun mereka cari. Keharuan dan kebahagiaan atas pertemuan orang tua dan anak itu pun merebak dalam acara pernikahan. Jaka Mruyung ditunjuk sebagai adipati Kutanegara menggantikan adipati Nglangak. Dalam masa pemerintahannya, ibukota Kutanegara dipindahkan ke hutan Pakis Aji yang kini telah berubah nama menjadi Ajibarang.

Babad Tanah Luhur Di Kerajaan Pajajaran, Prabu Silihwangi hendak digantikan oleh putranya, (Kamandaka) yaitu Prabu Banyakcatra. Namun syarat menjadi raja dalam kerajaan tersebut adalah sudah beristri, sedangkan Prabu Banyakcatra belum beristri. Oleh karena itu ia pergi berkelana untuk mencari pendamping hidup.

Prabu Banyakcatra pergi ke Kadipaten Pasirluhur. Di sana, dia menyamar menjadi rakyat jelata dengan nama samaran Kamandaka. Pasirluhur adalah 
Kadipaten yang dipimpin oleh seorang Adipati bernama Kandhadhaha. la pergi ke Kadipaten tersebut untuk menemui putri bungsu Adipati Kandhadhaha, Dewi Ciptarasa.

Kamandaka diangkat sebagai anak oleh Reksanata, patih Pasirluhur. Kamandaka sangat akrab dengan Dewi Ciptarasa. Namun suatu hari keakraban keduanya dipergoki oleh kakak Dewi Ciptarasa dan langsung dilaporkan kepada Adipati Kandhadhaha. Bagi Kandhadhaha, perbuatan Kamandaka telah merusak martabat Kadipatennya karena ia hanya rakyat jelata dan berani bercengkrama dengan anak Adipati. Adipati Kandhadhaha memerintah Patih Reksanata untuk membunuh Kamandaka. Sebagai seorang ayah angkat, Reksanata ragu melakukan tugas ini. Kamandaka dikejar-kejar oleh prajurit Pasirluhur. la terjun ke sungai dan bersembunyi di dalam gua yang ada di dalam sungai tersebut. Para prajurit melempari batu ke sungai. Mereka mengira Kamandaka telah mati karena melihat usus hewan mengapung di air yang mereka kira adalah usus Kamandaka. Para prajurit kemudian pulang untuk melaporkan kejadian itu kepada Sang Adipati.

Kamandaka terus berjalan menyusuri gua dan tiba kembali di Kadipaten Pasirluhur. Sementara itu Prabu Siliwangi di Pajajaran gelisah karena Banyakcatra atau Kamandaka, putra pertamanya tak kunjung kembali. la memerintahkan Raden Banyakngampar, adik Banyakcatra untuk mencari kakaknya.

Selang beberapa waktu, ada berita bahwa Kamandaka masih hidup. Adipati Pasirluhur mengadakan sayembara penangkapan Kamandaka. Raden Silihwarni atau Banyakngampar menyanggupi sayembara tersebut. Keduanya berhadapan. Banyakngampar dan Kamandaka bertarung seru. Pertempuran ini menewaskan seorang pengikut Banyakngampar, Banyakngampar juga pingsan dalam pertempuran ini. Setelah itu Kamandaka dikejar-kejar oleh prajurit Pasirluhur di bawah pasukan Silihwarni (Banyakcatra).

Kamandaka terus melakukan pelarian sehingga berhenti di suatu tempat dan ia berhadapan dengan Banyakngampar dan saling berhadapan. Saat itu Kamandaka mengeluarkan keris Kyai Mojang yang merupakan pusaka Kerajaan Pajajaran. Saat itu Banyakngampar kaget melihat senjata yang begitu ia kenalnya. la baru menyadari bahwa yang ia hadapi adalah Raden Banyakcatra, kakak kandungnya. Pertarunganpun batal.

Banyak Catra pergi ke timur Pasirluhur, yaitu dekat Sungai Megawa dan Sungi Mengaji. Disitu ia bertapa. Karena ketekunannya dalam bertapa, ia mendapatkan baju ajaib yang jika ia kenakan maka ia akan berubah menjadi seekor lutung (kera berekor panjang). Banyakcatra pergi ke Pasirluhur dengan wujud lutung. Saat ia bertemu Dewi Ciptarasa, Dewi Ciptarasa mengetahui bahwa ia adalah Kamandaka yang ia kenal.

Raden Pulebahas melamar Dewi Ciptarasa. Dewi Ciptarasa merasa ragu untuk menerima tawaran itu karena ia telah jatuh cinta kepada Kamandaka. Kamandakapun merencanakan sesuatu. Sesuai saran Kamandaka, Dewi Ciptarasa menerima lamaran Raden Pulebahas dengan dua syarat. Syarat pertama Raden Pulebahas tidak diperbolehkan membawa prajurit dan persenjataan. Syarat kedua adalah lutung yang ada disamping Dewi Ciptarasa tidak boleh diganggu. Raden Pulebahas menyetujui syarat tersebut. Pernikahan pun berjalan sesuai waktu yang telah ditentukan. Saat kirab pengantin, lutung kasarung menemani Dewi Ciptarasa. Saat Raden Pulebahas berbasa-basi menggendong si lutung, lutung tersebut menerkamnya. Raden Pulebahas terkejut dan berusaha melawan lutung itu. Namun lutung itu melumpuhkan Pulebahas. Namun di waktu itu lutung itu melepas pakaian 
ajaibnya dan ia berubah menjadi Kamandaka atau Raden Banyakcatra. Adipati Kandhadhaha terkejut karena lutung itu sebenarnya adalah Putra Prabu Siliwangi. Akhirnya hubungan Banyakcatra dengan Bewi Ciptarasa direstui oleh Adipati Kandhadhaha. Keduanyapun menikah dan hidup bahagia.

TRANSFORMASI CERITA KE DALAM NASKAH DRAMA

Tokoh dan Karakter
Pada dasarnya, teks drama ditulis dengan tujuan untuk dipentaskan di atas panggung. Akan tetapi, sebenarnya bukan hanya itu, teks drama juga dapat dinikmati dengan membaca, sebagaimana jenis karya sastra lain seperti puisi, cerpen, atau novel. Oleh karema itu, penulisan teks drama juga memiliki kaidah-kaidah tersendiri agar dapat dibaca dengan nyaman.

Karena merupakan hasil transformasi dari cerita rakyat, rancangan dasarnya tidak boleh melenceng dari teks hiponimnya. Akan tetapi ada pengolahan atau treatment yan berbeda dalam pengembangan unsur-unsur intrinsiknya. Langkah-langkah melakukan transformasi cerita rakyat ke dalam naskah lakon dimulai dengan merumuskan kembali gagasan, mendeskripsikan penokohan dan memberikan nama tokoh (termasuk di dalamnya tokoh-tokoh yang merupakan pengembangan dari teks hiponimnya), membuat garis besar cerita, mengembangkan garis besar isi cerita ke dalam dialog, serta membuat petunjukan pementasan yang biasanya ditulis di dalam tanda kurung, atau dengan huruf miring, atau huruf kapital, untuk membedakannya dengan dialog, serta memberikan judul pada teks drama yang sudah ditulis.

Dalam transformasi cerita rakyat ke dalam naskah lakon pada Djaka Mruyung: Si Anak Hilang dan Babad Pasir Luhur (Kamandaka), tokoh-tokoh tambahan dihadirkan untuk mendukung dan mengembangkan jalan cerita, memudahkan dialog, serta perancangan adegan.

Seorang tokoh bernama Casey dihadirkan dalam Djaka Mruyung: The Lost Boy. Tokoh Casey yang merupakan seorang dukun bayi yang membantu proses bersalin istri Munding Wilis. Di sini ia berperan sebagai tokoh yang mencairkan suasana dan mengangkat atmosfer pertunjukan yang serius menjadi menghibur. Tokoh ini juga dihadirkan dengan karakter yang dimodernisasi menjadi tokoh era kekinian, dengan mengenakan kacamata hitam, tas bermerek, dan ponsel.

Not long after that, a midwife with such a weird appearances shows up wearing kebaya, sunglasses, and branded bag. (Djaka Mruyung/Scene 3)

Selain itu, tokoh Casey (C) ini juga digambarkan piawai dalam bermain media sosial, memiliki akun Instagram dan berkomunikasi dengan keluarga kerajaan Inggris.

C : Excuse me. Looks like / got a notification form my instagram account. Wait a minute (she picks up her phone and begins scrolling). Hmm... The British Royal Family just messaged me. What? I am asked to help Prince Harry's wife, Megan Markle, to deliver her baby!!! OMG! OMG! Am I dreaming? Awwhh, I am so happy! (she is joyous while staring at her phone). (DM/3)

Dalam naskah lakon Kamandaka, juga terdapat penambahan tokoh, seperti penduduk dan penjahat, untuk mengembangkan alur cerita. Di samping itu ada juga Kyai Grendeng (KG) yang menjadi mediator Kamandaka (K) sehingga dapat berubah wujud menjadi Lutung.

KG : Open your eyes, young man

$\mathrm{K}$ : (Blinks) You are ... 
KG : I'm Kyai Grendeng. The one you met on your dreams.

$\mathrm{K}$ : Greetings, Kyai (bow)

KG : No need to be so formal, young man. So, you are currently in confusion I guess

$\mathrm{K}$ : Yes, Kyai. I'm confused on how to approach Dewi Ciptarasa, woman who I desired to be my wife in the future.

KG : You know young man, sometimes in life, we have to see our problems from different perspective

$\mathrm{K}:$ : Perspective? (puzzled face)

KG : Here (gives mask), hope this will help you solves your problems, young man. (Lights blinking repeatedly. KG exits)

$\mathrm{K}$ : That was... (realizes the mask on front) Perspective, right? (Tries on the mask, act like lutung). (Kamandaka/Scene 10)

Alur Pada alur cerita, terdapat pengembangan alur baik pada Djaka Mruyung dan Kamandaka. Beberapa adegan tambahan disisipkan, namun beberapa adegan ada yang dipersingkat maupun dihilangkan demi efektivitas pertunjukan. Perubahan-perubahan ini terjadi secara bertahap, menyesuaikan dengan situasi dan kondisi dalam proses latihannya. Alur terkait erat dengan konflik. Beberapa konflik juga dikembangkan untuk membuat pertunjukan menjadi lebih menarik buat penonton.

Latar Dalam proses transformasi, ruang lingkup cerita dikembangkan. Bahkan, terjadi rekreasi, dengan memodernisasi latar di beberapa babak. Pada scene 3, diceritakan Permaisuri Candramaya (PC) memanggil pelayannya melalui ponsel. Berikut adalah cuplikannya.

PC : (She rubs her stomach) It's been nine months since you're inside my womb. You will be born and see how beautiful the world is. I feel really bored staying here without doing anything. I guess reading a book will help. (She takes her phone and starts swiping the screen). Hello! Maid. Ah! (She is groaning). I will giving a birth. Could you get me a midwife in this duchy. Do it now! Ah! (Still groaning and put her phone on the bed). (DM/3)

Pada bagian lain, dalam percakapan antara Telangsa (T) dan Djaka Mruyung (DM) muncul penyebutan kata password dan merek kopi, yang tentu saja tidak sesuai dengan latar waktu yang sebenarnya dari keseluruhan cerita.

$\mathrm{T}$ : With whom and where am / speaking to? What is the password?

DM: With Djaka Mruyung in the middle of nowhere. Luwak White Coffee. Trust me, it works. (DM/10)

Penggunaan ragam informal khas anak mudamas kini juga muncul dalam satu bagian dialog antara RJ dan Kamandaka.

RJ : HOLY MOLY MOTHER FATHER!!! Is that a person?! (approach Kamandaka) Hello? Morning sunshine?? Dude, you awake? (pushed Kamandaka chest) Hello... moshi moshi... answer me please... (gasp) Oh he's breathing! This dude is still alive! Alright dude, I'll save you! Right now! (hesitant) Alright.. I'll save you now (holds Kamandaka) Man, you're heavy. $(\mathrm{K} / 10)$

Pada ujaran di atas, terdapat beberapa istilah yang merepresentasikan gaya bahasa khas anak muda, seperti holy moly, moshi-moshi, dude, dan man yang bersifat kekinian dan tidak sesuai dengan latar waktu cerita slinya. 
Konflik Dalam transformasi ke naskah lakon, disisipkan konflik tambahan. Dalam hal ini, konflik tambahan disisipkan untuk mengubah atmosfer cerita sesaat, yang dilakukan dengan menyisipkan dialog yang memancing tawa penonton. Berikut adalah contohnya.

$\mathrm{T}$ : (He is panic when he sees the blazing fire in front of his eyes). Oh my God, what the heck we gotta do? We do not only burn the snake, but also the whole forest! The fire is spreading and we cannot stop it. Oh, man... Water! Water! We need water! Where can we get water? There is no water here? (looks around and wipes his face in frustration) Oh, God, please help Baim. (He prays to God) (DM/12)

Baim adalah tokoh anak kecil dalam sinetron Indonesia yang cukup terkenal pada era tahun 2007-an. Pada naskah lakon Djaka Mruyung: The Lost Boy ini, nama itu dimunculkan untuk menimbulkan efek menghibur bagi penonton. Begitu pula, dengan tujuan yang sama, digunakan cara plesetan dalam naskah lakon Kamandaka, di saat terjadi kesalahpahaman antara dua tokoh, yaitu Djaka Mruyung dan Telangkas.

T : Huh? I can't believe you say that, Djaka Sembung. I thought we're friends!

$\mathrm{DM}:$ It's Mruyung. (DM/12)

KESALAHAN Menulis kreatif dalam bahasa Inggris bukan hanya melibatkan ketrampilan KALIMAT DALAM NASKAH LAKON menulis dengan berbagai unsur pembangunnya secara intrinsik, tetapi juga melibatkan ketrampilan bahasa Inggris. Bagi pembelajar bahasa Inggris, ini merupakan tantangan tersendiri.

Kesalahan Beberapa kesalahan gramatikal yang terjadi pada naskah lakon Djaka Gramatikal Mruyung the Lost Boy salah satunya dalam penggunaan possessive pronoun sebagai berikut:

I was asked to help you to deliver her baby.

Kalimat ini diucapkan Kasmirah sedang berbicara kepada Permaisuri Candramaya. la mengatakan bahwa dirinya akan membantu kelahiran bayi sang Permaisuri. la mengatakan / was asked to help you... tetapi kemudian pada lanjutan kalimat berikutnya, ketika you berubah menjadi possesive pronoun, digunakan kata her untuk merujuk kepada orang yang sama, yang seharusnya adalah your.

Kesalahan lain berupa double verb atau pengggunaan dua verba dalam satu kalimat seperti tampakpada kalimat di bawah ini:

\section{Does your client really is that famous Hollywood artist?}

Pada kalimat di atas, terdapat dua verba, yaitu does dan is. Dalam struktur kalimat ini, sebenarnya yang dibutuhkan hanyalah auxiliary verb is yang diletakkan di awal kalimat, sehingga kalimatnya menjadi Is your client that famous Hollywood artist?

Kesalahan juga ditemukan pada susunan kata, yaitu urutan yang terbalik antara satu kata dengan yang lain dalam satu kalimat, seperti terlihat pada kalimat berikut.

You really are smart, boss!

Kalimat yang menggunakan intensifier, yang dalam kalimat di atas diwakili kata really, seharusnya berpola 'subject + be + intensifier + adjective', sehingga susunan kalimat yang benar adalah You are really smart, Boss! 
Sementara itu, kesalahan gramatikal yang terjadi pada naskah lakon Kamandaka salah satunya berupa missing verb, yakni tidak adanya verba yang diperlukan dalam kalimat,sebagaimana ditunjukkan pada kalimat di bawah ini:

Banyakngampar ... interested with the prize of the competition, thousand chips of pure gold.

Kalimat di atas seharusnya berbentuk passive voice atau kalimat pasif. Akan tetapi, di sini terjadi kesalahan struktur kalimat, yaitu tidak adanya auxiliary verb atau kata antuu kata kerja yang menjadi syarat mutlak dalam pembentukan kalimat pasif. Pada kalimat di atas seharusnya terdapat auxiliary verb is di antara subjek (Banyakngampar) dan kata kerja bentuk ketiga (interested) sehingga kalimat yang benar adalah Banyakngampar was interested with the prize of the competition....

Kesalahan lain yang ditemukan berupa ketidakkonsistenan dalam penggunaan tense atau kala. Contohnya dapat dilihat pada kalimat berikut:

Without knowing that the men he is supposed to find is his brother, he goes alone to a fighting competition in Panagih as Adipati told him to, and he refused to bring any soldier.

Pada kalimat majemuk di atas terjadi inkonsistensi penggunaan tense, yakni simple present pada klausa pertama (is) dan kedua (goes) serta simple past pada klausa ketiga. Karena kejadian sudah lampau, seharusnya ketiga verba tersebut berbentuk simple past sebagai berikut: Without knowing that the men he was supposed to find is his brother, he went alone to a fighting competition in Panagih as Adipati told him to, and he refused to bring any soldier.

Kesalahan berupa double verb juga terjadi di sini, sebagaimana dapat diamati pada kalimat berikut:

Here I will say this, Adipati, now with my true identity I, Raden Banyakcatra, am truly are affectionate to your daughter, I adore her the very first time I met her.

Pada kalimat tersebut, terdapat dua auxiliary verb yaitu am dan are. Ini tentu saja tidak sesuai dengan kaidah tata bahasa Inggris yang mensyaratkan adanya satu verba utama saja dalam satu klausa atau kalimat tunggal. Oleh karena itu, bentuk kalimat yang benar adalah: Here / will say this, Adipati, now with my true identity I, Raden Banyakcatra, am truly affectionate to your daughter, I adore her the very first time I met her.

Sementara itu, kesalahan lain dalam penggunaan bentuk verba juga ditemukan pada kalimat berikut ini:

And I want her to be my wife, the future queen of this kingdom, to accompany me to leads the reign from above.

Pada contoh kalimat di atas, terjadi kesalahan pada bentuk verba to infinitive yang seharusnya to + verb 1 tetapi menjadi to + verb-s. Oleh karena itu bentuk yang benar adalah: And I want her to be my wife, the future queen of this kingdom, to accompany me to lead the reign from above.

Kesalahan Dalam tataran leksikal, kesalahan terjadi dalam tataran diksi, yaitu pemilihan Leksikal kata yang tidak sesuai.

Everyone shouts happily and tossing their cup to one another. 
Makna yang dimaksudkan dari klausa tossing their cup to one another di atas sebenarnya adalah 'mendentingkan gelas satu sama lain'. Oleh karena itu, kosa kata yang benar bukanlah toss, yang berarti melempar, tetapi toast yang berarti mengangkat dan saling membenturkan gelas sebagai perayaan keberhasilan. Meskipun demikian, istilah toasting juga kurang tepat jika diikuti objek their cup to one another. Akan lebih tepat jika kata toasting diikuti dengan frasa their success.

KESIMPULAN Di dalam transformasi cerita rakyat Banyumas Babad Pasir Luhur dan Djaka Mruyung ke dalam naskah lakon berbahasa Inggris, terdapat perubahan dalam hal tokoh dan karakter, alur, latar, serta konflik. Hal ini dimaksudkan agar cerita rakyat dapat disajikan kepada para penonton dengan nuansa yang lebih modern dan menyegarkan.

Sementara itu dalam hal aspek kebahasaan, terdapat kesalahan dalam pemakaian bahasa Inggris, baik secara gramatikal maupun leksikal. Kesalahan gramatikal yang terjadi berupa kesalahan penggunaan possesive pronoun, adanya double verb, missing verb, susunan kata yang tidak sesuai, ketidakkonsistenan dalam penggunaan tense, dan kesalahan bentuk verb. Sementara itu, kesalahan leksikal yang terjadi berupa ketidaktepatan diksi atau pilihan kata.

DAFTAR PUSTAKA Arifin. 2018. Transformasi Novel Si Jamin Dan Si Johan Karya Merari Siregar Ke Dalam Naskah Drama.

Agustina, Arinta. 2019. Karya Adaptasi: Sebuah Pemiskinan atau Pengayaan Ide. http://digilib.isi.ac.id/747/. Diakses pada 3 April 2019.

Gillespie. 2014. The Art of Literary Adaptation and English-Language Film Interpretations of Russian Literature Anna Karenina

Damono. 2005. Pegangan Penelitian Sastra Bandingan. Jakarta: Pusat Bahasa

Eneste, Pamusuk. 1991. Novel dan Film. Jakarta: Nusa Indah

Hasanuddin WS. 1996. Drama Karya dalam Dua Dimensi: Kajian Teori, Sejarah dan Analisis. Bandung: Angkasa

Hutcheon, Linda. 2006. A Theory of Adaptation. New York: Routledge

Leitch, Thomas. 2018. "Adaptation: The Genre". Adaptation, 1 (2): 106-120

Perdikaki, Katerina. 2017. "Film Adaptation as Translation: An Analysis of Adaptation Shifts In Silver Linings Playbook". Anafora, 2: 249-265

Sermsook, K, J Liamnimitr \& R Pochakorn. 2017. "An Analysis of Errors inWritten English Sentences: A Case Study of Thai EFL Students". English Language Teaching Journal, $10(3)$

Tarigan, Henry Guntur. 1986. Menulis Sebagai Suatu Keterampilan Berbahasa. Bandung: Angkasa

Tsai, ST, TC Chang \& YF Huang. 2016. "An Intelligent Recommendation System for Animation Scriptwriters' Education". Eurasia Journal of Mathematics, Science \& Technology Education, 12 (5): 1139-1151. doi:10.12973/eurasia.2016.1502a

Sumpeno. 2014. Akulturasi Budaya dalam Bentuk Adaptasi Drama Karya Sutradara Suyatna Anirun Dari Studiklub Teater Bandung. Bandung: Studiklub Teater

Watni, Puji. 2014. "Transformasi Cerpen Di Atas Sajadah Cinta Karya Habiburrahman El Shirazy Menjadi Naskah Drama Panggung Dalam Pembelajaran Apresiasi Drama di Kelas X SMA". Jurnal Surya Bahtera, 2 (15)

Copyright (C) 2020 Leksema: Jurnal Bahasa dan Sastra 
200 Leksema: Jurnal Bahasa dan Sastra Vol. 5 No. 2 